\title{
Anti-melanogenic activity of methanolic extract from leaves of Sorbaria sorbifolia var. stellipila Max. on a-MSH-stimulated B16 melanoma 4A5 cells
}

Kosuke Nishi ${ }^{1,2,3^{*}}$ D, Mizuki Mori ${ }^{2}$, Daisuke Nakayama ${ }^{1}$, Junna Sato ${ }^{2}$, In-Hae Kim ${ }^{1}$, Minju Kim ${ }^{4}$, Songmun Kim ${ }^{4}$ and Takuya Sugahara ${ }^{1,2,3}$

\begin{abstract}
Background: Melanin is a pigment, which is widely distributed in organisms. In humans, melanin pigments determine eye, hair, and skin color and protect the skin from damage by ultraviolet radiation; however, immoderate distribution of melanin in the skin causes discoloration. In the present study, we screened methanolic extracts from leaves of 47 plant species, most of which are native to East Asia, for the inhibitory activity against melanogenesis.

Methods: B16 melanoma 4A5 cells were used in all assays conducted in this study. Melanin content assay was performed using methanolic extracts from leaves of 47 plant species. Cytotoxicity of the extract from leaves of Sorbaria sorbifolia var. stellipila Max. (SME) was evaluated by WST-8 assay. Tyrosinase activity was determined using the lysate of a-MSH-stimulated B16 melanoma 4A5 cells and L-dopa as a colorimetric substrate. Melanogenic gene expression was determined by quantitative reverse transcription-polymerase chain reaction (qRT-PCR).

Results: SME showed the highest inhibitory activity among tested samples without cytotoxicity. SME exhibited the inhibition potency for the enzymatic activity of tyrosinase. In addition, QRT-PCR result displayed that SME downregulates the expression of melanogenic genes including tyrosinase, TRP-1, TRP-2, and the transcription factor MITF.
\end{abstract}

Conclusion: Overall results revealed that the extract from leaves of S. sorbifolia var. stellipila Max. has a potential to be used as a skin whitening agent.

Keywords: B16 melanoma 4A5 cells, Sorbaria sorbifolia, Melanin, Tyrosinase, MITF, Tyrosinase-related protein

\section{Background}

Melanogenesis is the production of melanin pigments in melanosomes of melanocytes (D'Mello et al. 2016). Melanin pigments are widely distributed in organisms ranging from bacteria, plants, to animals (Solano 2014). In humans, melanin pigments determine eye, hair, and skin color and protect the skin from damage by ultraviolet (UV) radiation (Costin and Hearing 2007); however, immoderate distribution of melanin in the skin causes

\footnotetext{
* Correspondence: nishi.kosuke.mx@ehime-u.ac.jp

1 Department of Bioscience, Graduate School of Agriculture, Ehime University, 3-5-7 Tarumi, Matsuyama, Ehime 790-8566, Japan

${ }^{2}$ Department of Biological Resources, Faculty of Agriculture, Ehime University, Matsuyama, Ehime, Japan

Full list of author information is available at the end of the article
}

discoloration (Skoczyńska et al. 2017). UV radiation stimulates the production of $\alpha$-melanocyte-stimulating hormone $(\alpha-\mathrm{MSH})$ from keratinocytes and gene expression of melanocortin 1 receptor (MC1R), one of whose endogenous ligands is $\alpha-\mathrm{MSH}$ (Bolognia et al. 1989; Chakraborty et al. 1995; Yang et al. 1997; Corre et al. 2004; Barnetson et al. 2006). The binding of $\alpha-\mathrm{MSH}$ to MC1R stimulates adenylyl cyclase to increase the cAMP level, leading to enhanced activity of cAMP-dependent protein kinase A (Buscà and Ballotti 2000). The enzyme subsequently leads to phosphorylation of cAMP response element-binding protein that expresses microphthalmia-associated transcription factor (MITF) gene (Rodríguez and Setaluri 2014). MITF, a major transcription factor for melanogenesis, 
induces the expression of melanogenic enzymes including tyrosinase, tyrosinase-related protein-1 (TRP-1), and TRP-2 (Vachtenheim and Borovanský 2010). Tyrosinase mediates hydroxylation of L-tyrosine to 3-hydroxy-L-tyrosine (Ldopa) and oxidizes L-dopa into L-dopaquinone. TRP-2 oxidizes dopachrome to 5,6-dihydroxyindole-2-carboxylic acid (DHICA), whereas TRP-1 catalyzes the conversion of DHICA to carboxylated indole-quinone via oxidation reaction (Barber et al. 1984; Kobayashi et al. 1994). In the presence of thiol materials, dopaquinone reacts with them, leading to the formation of pheomelanin (Lee et al. 2016). On the other hand, in the absence of thiol materials, dopaquinone is converted to eumelanin (Burchill et al. 1986). The proportion and amount of pheomelanin and eumelanin mainly determine the phenotype of human skin color (Ito and Wakamatsu 2003).

Natural products are well recognized as important sources for developing biologically active substances. Natural products with diverse structures exhibit various biological functions such as antifungal, anticancer, and pesticidal activities. Several extracts from natural resources have been reported to exhibit anti-melanogenic activity (Bourhim et al. 2018; Seo et al. 2019; Wang et al. 2019). Extracts with the anti-melanogenic activity can be used as skin whitening cosmetics agents (Smit et al. 2009); thus, investigations on natural products possessing an inhibition potency for melanogenesis were performed in the present study. After screening methanolic extracts from leaves of various plant species, most of which are native to East Asia, for the inhibitory activity on melanogenesis, we found the anti-melanogenesis activity in the extract from Sorbaria sorbifolia var. stellipila Max. Our results indicate that the leaves of S. sorbifolia var. stellipila Max. would have a potential to be used as a skin whitening cosmetics agent.

\section{Methods}

\section{Reagents}

Dulbecco's modified Eagle medium (DMEM), fetal bovine serum (FBS), penicillin, streptomycin, L-tyrosine, Triton$\mathrm{X} 100$, and synthetic melanin were obtained from SigmaAldrich (St. Louis, MO, USA). $\alpha-\mathrm{MSH}$ was purchased from Abcam (Cambridge, UK). 4-Hydroxyphenyl $\beta$-Dglucopyranoside (arbutin) was purchased from Tokyo Chemical Industry (Tokyo, Japan). L-Dopa was purchased from Nacalai Tesque (Kyoto, Japan). All other chemicals were purchased from Fujifilm Wako Pure Chemical (Osaka, Japan) or Nacalai Tesque unless otherwise noted.

\section{Plant material and extraction}

Fresh leaves of 47 plant species were collected in Republic of Korea and identified by plant taxonomist, Dr. SanSub Han at Jeonbuk National University, Republic of Korea. The leaves were dried under shade at room temperature, pulverized using a grinder (HMF-3260S,
Hanil Electric, Seoul, Republic of Korea) up to $0.6 \mathrm{~mm}$. One kilogram of powdered leaves was extracted twice in $1 \mathrm{~L}$ of methanol per each extraction for 2 days and filtered. The combined filtrates were concentrated using a rotary vacuum evaporator (NE-1101, EYELA, Tokyo, Japan) at $35^{\circ} \mathrm{C}$, and the concentrate was extracted in 50 $\mathrm{mL}$ of water. The extract was dried using a freeze dryer (FD5505, ilShinBioBase, Dongducheon, Republic of Korea). The dried extract of each sample was dissolved in dimethyl sulfoxide (DMSO) and used for the experiments described below. The herbarium specimen of $S$. sorbifolia var. stellipila Max. has been deposited at the Department of Biological Environment, College of Agriculture and Life Sciences, Kangwon National University, Republic of Korea, with voucher number KPNS-534.

\section{Cell culture}

B16 melanoma 4A5 cells were obtained from Riken Cell Bank (Tsukuba, Japan) and cultured in DMEM supplemented with $10 \%$ FBS, $100 \mathrm{U} / \mathrm{mL}$ penicillin, and $100 \mu \mathrm{g} /$ $\mathrm{mL}$ streptomycin at $37^{\circ} \mathrm{C}$ in a humidified atmosphere with $5 \% \mathrm{CO}_{2}$.

\section{Melanin content assay}

B16 melanoma 4 A5 cells were seeded at $3.0 \times 10^{4}$ cells/ well in a 24-well culture plate (BD Falcon, Franklin Lakes, NJ, USA) and preincubated at $37^{\circ} \mathrm{C}$ for $24 \mathrm{~h}$. After removing culture media, $1 \mathrm{~mL}$ of fresh DMEM containing 10\% FBS, $100 \mathrm{nM} \alpha$-MSH, $1.6 \mathrm{mM}$ L-tyrosine, and $1 \mu \mathrm{L}$ of a plant leaf extract or of $100 \mathrm{mM}$ arbutin dissolved in DMSO was added to each well and cultured at $37^{\circ} \mathrm{C}$ for $72 \mathrm{~h}$. One milliliter of fresh DMEM containing $10 \% \mathrm{FBS}, 100 \mathrm{nM} \alpha-\mathrm{MSH}, 1.6 \mathrm{mM} \mathrm{L}$-tyrosine, and $1 \mu \mathrm{L}$ of DMSO was added to the positive control wells, whereas $1 \mathrm{~mL}$ of fresh DMEM containing 10\% FBS, 1.6 mM L-tyrosine, and $1 \mu \mathrm{L}$ of DMSO to the negative control wells. After removing culture media, each well was washed with phosphate-buffered saline (PBS, pH 7.4) once. After removing PBS, $200 \mu \mathrm{L}$ of $1 \mathrm{M} \mathrm{NaOH}$ containing $10 \%$ DMSO were added to each well and incubated at $80^{\circ} \mathrm{C}$ for $1 \mathrm{~h}$ to lyse cells. After incubation, $100 \mu \mathrm{L}$ of the cell lysates were transferred to a 96-well microplate, and the absorbance was measured at $415 \mathrm{~nm}$ using a microplate reader (Model 680, Bio-Rad Laboratories, Richmond, CA, USA). The amount of melanin was determined according to a standard curve prepared with synthetic melanin standard solutions. Protein concentration of each cell lysate was measured using a DC protein assay kit (Bio-Rad Laboratories) with bovine serum albumin as a protein standard according to the manufacturer's instructions. Data are shown as the amount of melanin per the protein amount of each cell lysate. 
Table 1 Primers used for qRT-PCR

\begin{tabular}{ll}
\hline Gene & Sequence (5' to 3') \\
\hline MITF & 5'-TCGCCTGATCTGGTGAATCG-3' (sense) \\
& 5'-TCTGCCTGGTGCTGTACAAG-3' (antisense) \\
Tyrosinase & 5'-TCGTATCTGGCCATGGCTTC-3' (sense) \\
& 5'-ATGAGGAGTGGCTGCCTTC-3' (antisense) \\
TRP1 & 5'-GAGCCTTCTTTCTCCCTTCC-3' (sense) \\
& 5'-TCCCATCAAGTCATCAGTGC-3' (antisense) \\
TRP2 & 5'-TTGCCCTACTGGAACTTTGC-3' (sense) \\
& 5'-TGGGTCATCTTGTCTTGCTG-3' (antisense) \\
& 5'-CACTCTTCCAGCCTTCCTTCC-3' (sense) \\
& 5'-GTGTTGGCGTACAGGTCTTTG-3' (antisense)
\end{tabular}

\section{Cell viability assay}

A colorimetric cell viability assay was carried out using Cell Count Reagent SF that contains (2-(2-methoxy-4-nitrophenyl)-3-(4-nitrophenyl)-5-(2,4-disulfophenyl)-2Htetrazolium, monosodium salt (WST-8, Nacalai Tesque). B16 melanoma 4 A5 cells were seeded at $3.0 \times 10^{3}$ cells/ well in a 96-well culture plate (Corning, Corning, NY, USA) and preincubated at $37^{\circ} \mathrm{C}$ for $24 \mathrm{~h}$. After removing culture media, $100 \mu \mathrm{L}$ of fresh DMEM containing $10 \%$ FBS, $100 \mathrm{nM} \alpha-\mathrm{MSH}, 1.6 \mathrm{mM}$ L-tyrosine, and $0.1 \mu \mathrm{L}$ of the methanolic extract from leaves of S. sorbifolia var. stellipila Max. (SME) dissolved in DMSO or of DMSO alone (control) was added to each well and cultured at $37^{\circ} \mathrm{C}$ for $72 \mathrm{~h}$. After removing culture media, $100 \mu \mathrm{L}$ of fresh DMEM containing $10 \%$ WST-8 solution was added to each well and incubated at $37^{\circ} \mathrm{C}$ for $1 \mathrm{~h}$. The absorbance was then measured at $450 \mathrm{~nm}$ using a microplate reader (Model 680, Bio-Rad Laboratories). Relative cell viability was expressed by comparing the absorbance of each sample well with that of the control well.

\section{Tyrosinase activity assay}

Tyrosinase activity was determined according to a previously reported method (Lee et al. 2015) with slight modifications. B16 melanoma 4A5 cells were seeded at $3.0 \times 10^{6}$ cells/dish in a $100-\mathrm{mm}$ culture dish (BD Falcon) and precultured at $37^{\circ} \mathrm{C}$ for $24 \mathrm{~h}$. After removing culture media, $10 \mathrm{~mL}$ of fresh DMEM containing 10\% FBS, 100 $\mathrm{nM} \alpha-\mathrm{MSH}$, and $1.6 \mathrm{mML}$-tyrosine were added to the dish and cultured at $37^{\circ} \mathrm{C}$ for $72 \mathrm{~h}$. After removing culture media, cells were washed with PBS once. After removing PBS, cells were suspended in $2 \mathrm{~mL}$ of $10 \mathrm{mM}$ sodium phosphate buffer (NaPB, pH 7.4) containing 0.01\% Triton$\mathrm{X} 100$ and $50 \mathrm{nM}$ phenylmethylsulfonyl fluoride and frozen at $-35^{\circ} \mathrm{C}$. After thawing the cells, the suspension was centrifuged at $13,000 \mathrm{rpm}$ for $10 \mathrm{~min}$ at $4{ }^{\circ} \mathrm{C}$, and the supernatant was used as a tyrosinase solution.

Every reaction of tyrosinase activity assay consisted of $50 \mu \mathrm{L}$ of $2 \mathrm{mML}$-dopa and $100 \mu \mathrm{L}$ of $10 \mathrm{mM} \mathrm{NaPB}$ containing $1 \mu \mathrm{L}$ of SME, $1 \mu \mathrm{L}$ of $100 \mathrm{mM}$ arbutin, or $1 \mu \mathrm{L}$ of DMSO alone (control) in each well of a 96-well microplate. After preincubation at $37^{\circ} \mathrm{C}$ for $10 \mathrm{~min}, 50 \mu \mathrm{L}$ of the tyrosinase solution $(0.7 \mathrm{mg}$ protein $/ \mathrm{mL})$ was added to each well of the microplate and incubated at $37{ }^{\circ} \mathrm{C}$ for $60 \mathrm{~min}$. The produced amount of dopachrome was determined by measuring the absorbance at $450 \mathrm{~nm}$ using a microplate reader (Model 680, Bio-Rad Laboratories).

\section{Quantitative reverse transcription-polymerase chain reaction (qRT-PCR)}

B16 melanoma 4 A5 cells were seeded at $5.0 \times 10^{4}$ cells/ well in a 24-well culture plate and preincubated at $37^{\circ} \mathrm{C}$

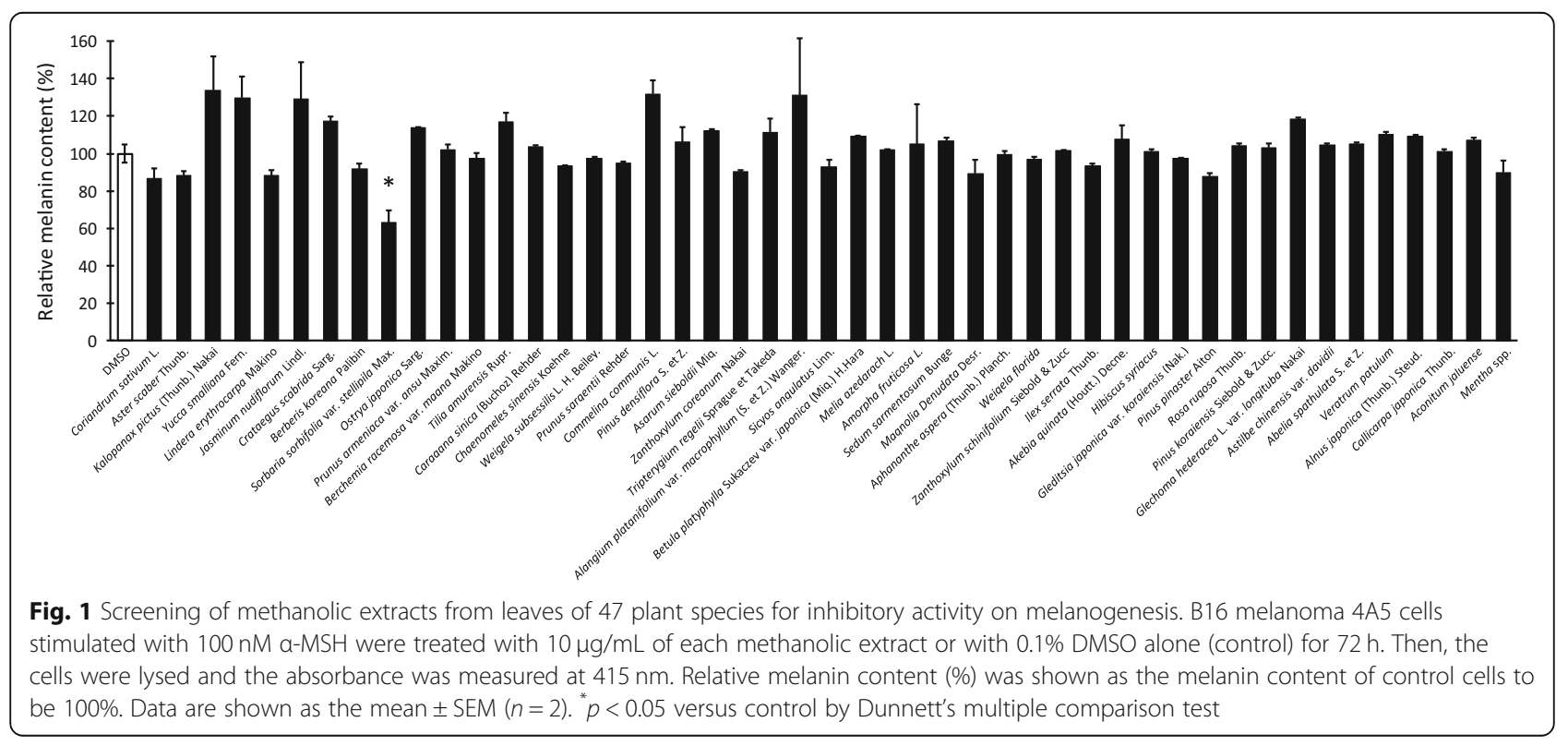


for $24 \mathrm{~h}$. After removing culture media, $1 \mathrm{~mL}$ of fresh DMEM containing 10\% FBS, $100 \mathrm{nM} \alpha-\mathrm{MSH}, 1.6 \mathrm{mM} \mathrm{L}-$ tyrosine, and $1 \mu \mathrm{L}$ of SME was added to each well and cultured at $37^{\circ} \mathrm{C}$ for $24 \mathrm{~h}$. One milliliter of fresh DMEM containing 10\% FBS, $100 \mathrm{nM} \alpha-\mathrm{MSH}, 1.6 \mathrm{mM}$ L-tyrosine, and $1 \mu \mathrm{L}$ of DMSO was added to the positive control wells, whereas $1 \mathrm{~mL}$ of fresh DMEM containing $10 \%$ FBS, $1.6 \mathrm{mM}$ L-tyrosine, and $1 \mu \mathrm{L}$ of DMSO to the negative control wells. After removing culture media, $1 \mathrm{~mL}$ of Sepasol RNA I Super G (Nacalai Tesque) was added to extract RNA from cells. Following total RNA extraction, cDNA synthesis and real-time PCR were performed according to a previously described method (Nishi et al. 2011). The primer pairs used in this study for amplification were shown in Table 1 . $\beta$-Actin was used as an internal control to normalize the real-time PCR result.

\section{Statistical analysis}

Data obtained are expressed as the mean \pm SEM. Statistical analyses were performed using GraphPad Prism version 7.02 (GraphPad Software, La Jolla, CA, USA). One-way analysis of variance followed by Dunnett's multiple comparison test or Tukey's multiple comparison test was used to assess the statistical significance. $p$ values of less than 0.05 were considered statistically significant.

\section{Results}

Screening of plant leaf extracts

To find a novel plant species with the inhibitory activity on melanogenesis, methanolic extracts from leaves of 47 plant species were prepared and screened. B16 melanoma 4A5 cells were used as a model of melanocytes in this study. When various methanolic extracts were subjected to the melanin assay at $10 \mu \mathrm{g} / \mathrm{mL}$, the extract from leaves of S. sorbifolia var. stellipila Max. (SME) showed the highest inhibitory activity among tested samples with a statistical significance against control (Fig. 1).

\section{Effect of SME on melanogenesis}

Next, we investigated the characteristics of SME. B16 melanoma 4A5 cells were treated with various concentrations of SME for $72 \mathrm{~h}$, and then, the amount of melanin was determined by measuring the absorbance of cell lysates. As shown in Fig. 2a, melanin was produced in $\alpha-\mathrm{MSH}-$ stimulated cells significantly higher than in unstimulated cells. We found that SME suppresses the melanogenesis in a dose-dependent manner. Melanogenesis was significantly suppressed by treating B16 melanoma 4A5 cells with $10 \mu \mathrm{g} / \mathrm{mL}$ of SME compared with DMSO alone. Arbutin, a hydroquinone glycoside traditionally used as a skin whitening agent (Sakuma et al. 1999; Hu et al. 2009), was used for comparison and tended to suppress (a)

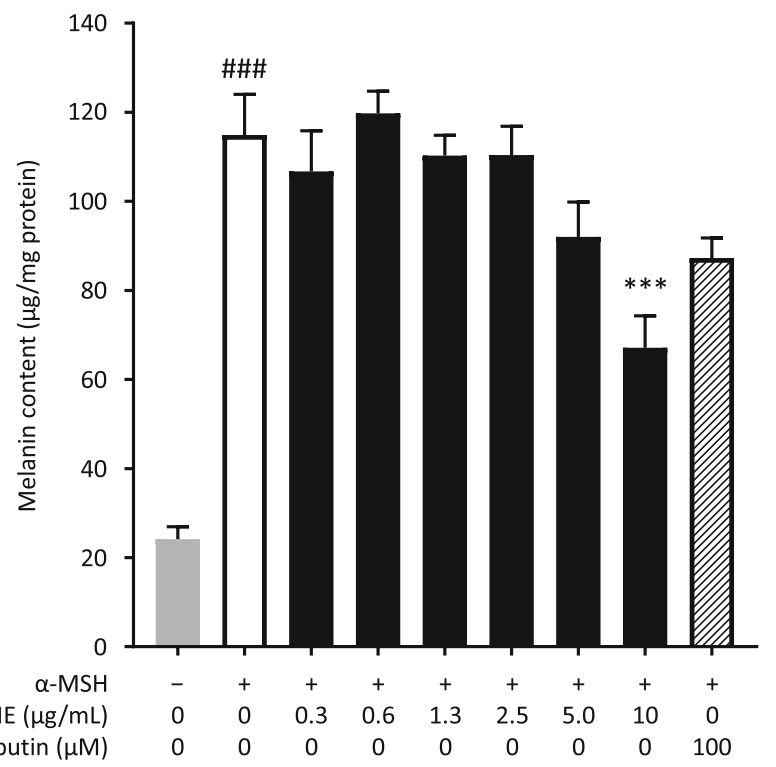

(b)

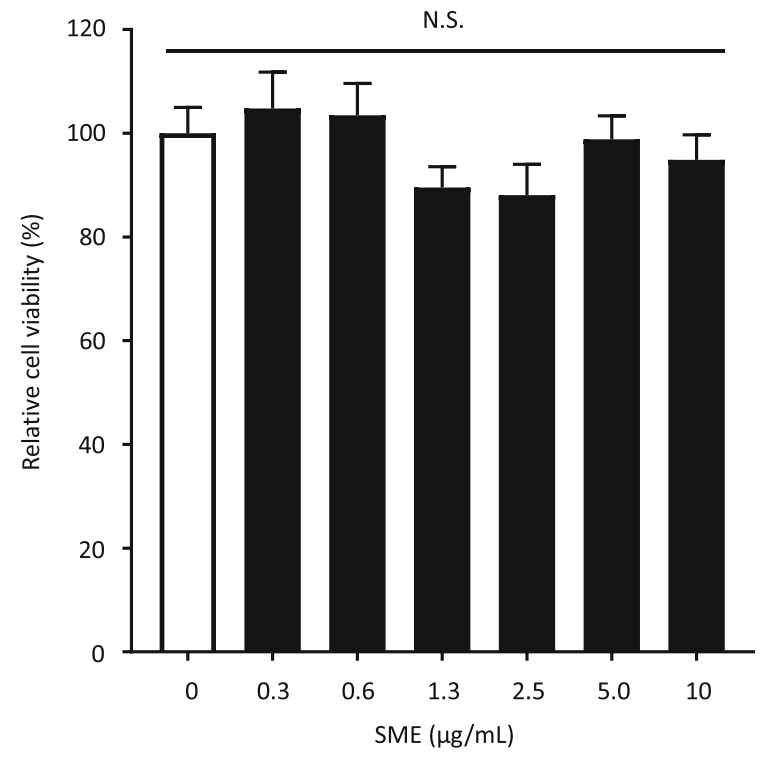

Fig. 2 Effects of SME on melanogenesis and cell viability of B16 melanoma 4A5 cells. a Cellular melanogenesis of B16 melanoma 4 A5 cells treated with SME. a-MSH-stimulated cells were treated with SME $(0.3-10 \mu \mathrm{g} / \mathrm{mL})$ or with $100 \mu \mathrm{M}$ arbutin for $72 \mathrm{~h}$ and then lysed. Positive control cells were treated with $100 \mathrm{nM}$ a-MSH and $0.1 \%$ DMSO alone, whereas negative control cells with $0.1 \%$ DMSO alone. The absorbance of cell lysates was measured at $415 \mathrm{~nm}$. Values represent the mean \pm SEM from three independent experiments. \#\#\# $<0.001$ versus negative control, ${ }^{* * *} p<0.001$ versus positive control by Tukey's multiple comparison test. b Cell viability of B16 melanoma 4A5 cells treated with SME. a-MSHstimulated cells were treated with SME $(0.3-10 \mu \mathrm{g} / \mathrm{mL})$ or with $0.1 \%$ DMSO alone for $72 \mathrm{~h}$. Values represent the mean \pm SEM from three independent experiments. NS indicates no statistical significance versus control by Dunnett's multiple comparison test 
melanogenesis of B16 melanoma 4A5 cells. We also evaluated the cytotoxic potential of SME to B16 melanoma 4A5 cells by the WST-8 assay. Cells seeded in a 96-well culture plate were treated with various concentrations of SME or with DMSO alone (control) for $72 \mathrm{~h}$, and then, the WST-8 reagent was added to each well of the culture plate. As shown in Fig. 2b, there was no statistically significant difference in the live cell number between SMEtreated and non-treated cells. On the basis of the result, SME was used at $10 \mu \mathrm{g} / \mathrm{mL}$ or lower concentrations in the subsequent experiments.

\section{Effect of SME on tyrosinase activity}

We next investigated how SME suppresses melanogenesis. Tyrosinase prepared from B16 melanoma 4A5 cells stimulated with $\alpha-\mathrm{MSH}$ was mixed with $2.5,5.0$, or $10 \mu \mathrm{g} / \mathrm{mL}$ of SME. Tyrosinase activity was subsequently measured using L-dopa as a colorimetric substrate. As shown in Fig. 3, SME inhibited tyrosinase activity in a dose-dependent manner. The enzyme activity was significantly inhibited by 5.0 and $10 \mu \mathrm{g} / \mathrm{mL}$ of SME. Arbutin, a well-known tyrosinase inhibitor, also significantly suppressed the enzyme activity. Tyrosinase activity was

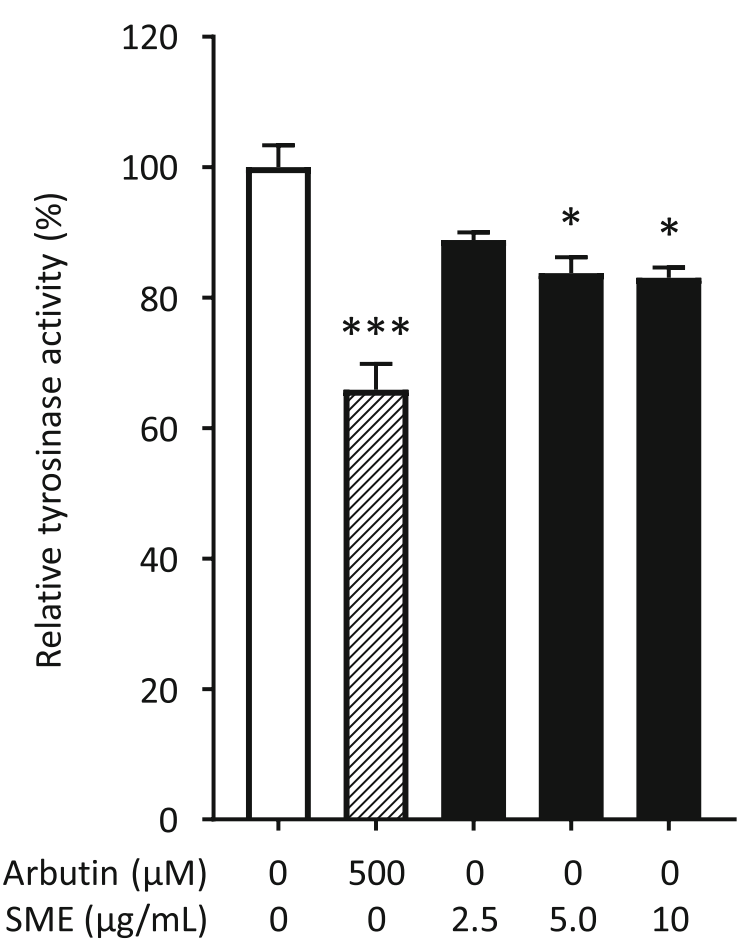

Fig. 3 Effect of SME on tyrosinase activity. Tyrosinase activity was measured using L-dopa as a substrate in the presence of SME (2.5$10 \mu \mathrm{g} / \mathrm{mL}$ ), of $500 \mu \mathrm{M}$ arbutin, or of $0.1 \%$ DMSO (control). The produced amount of dopachrome was determined by measuring the absorbance at $450 \mathrm{~nm}$. The assay was performed in quadruplicate. Values represent the mean \pm SEM. ${ }^{*} p<0.05,{ }^{* * *} p<$ 0.001 versus control by Dunnett's multiple comparison test suppressed by $34 \%$ by treating with $0.5 \mathrm{mM}$ arbutin, while that was inhibited by $17 \%$ with $10 \mu \mathrm{g} / \mathrm{mL}$ of SME.

\section{Effect of SME on a-MSH-induced melanogenic gene expression}

To investigate whether SME affects the expression of melanogenesis genes, qRT-PCR was performed. As shown in Fig. 4, the expression of melanogenic genes, including tyrosinase, TRP-1, TRP-2, and transcription factor MITF, was significantly upregulated by the stimulus with $\alpha-\mathrm{MSH}$. qRT-PCR experiment displayed that SME significantly reduces the transcriptional level of MITF in a dose-dependent manner. The MITF expression level in B16 melanoma 4A5 cells decreased to that in unstimulated cells by treating cells with $10 \mu \mathrm{g} / \mathrm{mL}$ of SME. SME also significantly reduced the transcription of tyrosinase, TRP-1, and TRP-2 genes (Fig. 4).

\section{Discussion}

In this study, methanolic extracts from leaves of 47 plant species, most of which are native to East Asia, were screened, and the extract from leaves of S. sorbifolia var. stellipila Max. (SME) showed the highest inhibitory activity among tested samples with a statistical significance. Among tested species, S. sorbifolia var. stellipila Max., Crataegus scabrida Sarg., Prunus armeniaca var. ansu Maxim., Chaenomeles sinensis Koehne, Prunus sargentii Rehder, and Rosa rugosa Thunb. belong to Rosaceae family; however, the inhibitory activity on melanogenesis was observed in the extract of S. sorbifolia var. stellipila Max. only (Fig. 1), suggesting that the bioactive molecule might not be commonly found in the plants of Rosaceae family, but also be specifically produced in S. sorbifolia var. stellipila Max only.

It has been reported that several cytotoxic constituents are contained in methanolic extract from the aerial parts of S. sorbifolia var. stellipila Max. (Kim et al. 1997). We thus evaluated the cytotoxic potential of SME to B16 melanoma 4A5 cells by the WST- 8 assay and confirmed that SME does not affect the live cell number of B16 melanoma 4A5 cells up to $10 \mu \mathrm{g} / \mathrm{mL}$ (Fig. 2b). The melanogenesis-suppressive activity of SME was thus revealed to be attributed to the biological activity of constituent(s) in SME but not to cytotoxicity.

Melanogenesis is known to be modulated by three melanogenic enzymes: tyrosinase, TRP-1, and TRP-2. Among these three enzymes, tyrosinase (EC 1.14.18.1) is the pivotal enzyme responsible for the conversion of $\mathrm{L}$ tyrosine to dopaquinone via L-dopa and controls the rate of melanin biosynthesis (Hearing and Tsukamoto 1991). For developing anti-melanogenic agents, direct targeting of the component involved in melanin synthesis, such as tyrosinase, is common (Gunia-Krzyżak et al. 2016; Bin et al. 2016). In fact, most of skin whitening agents on the 

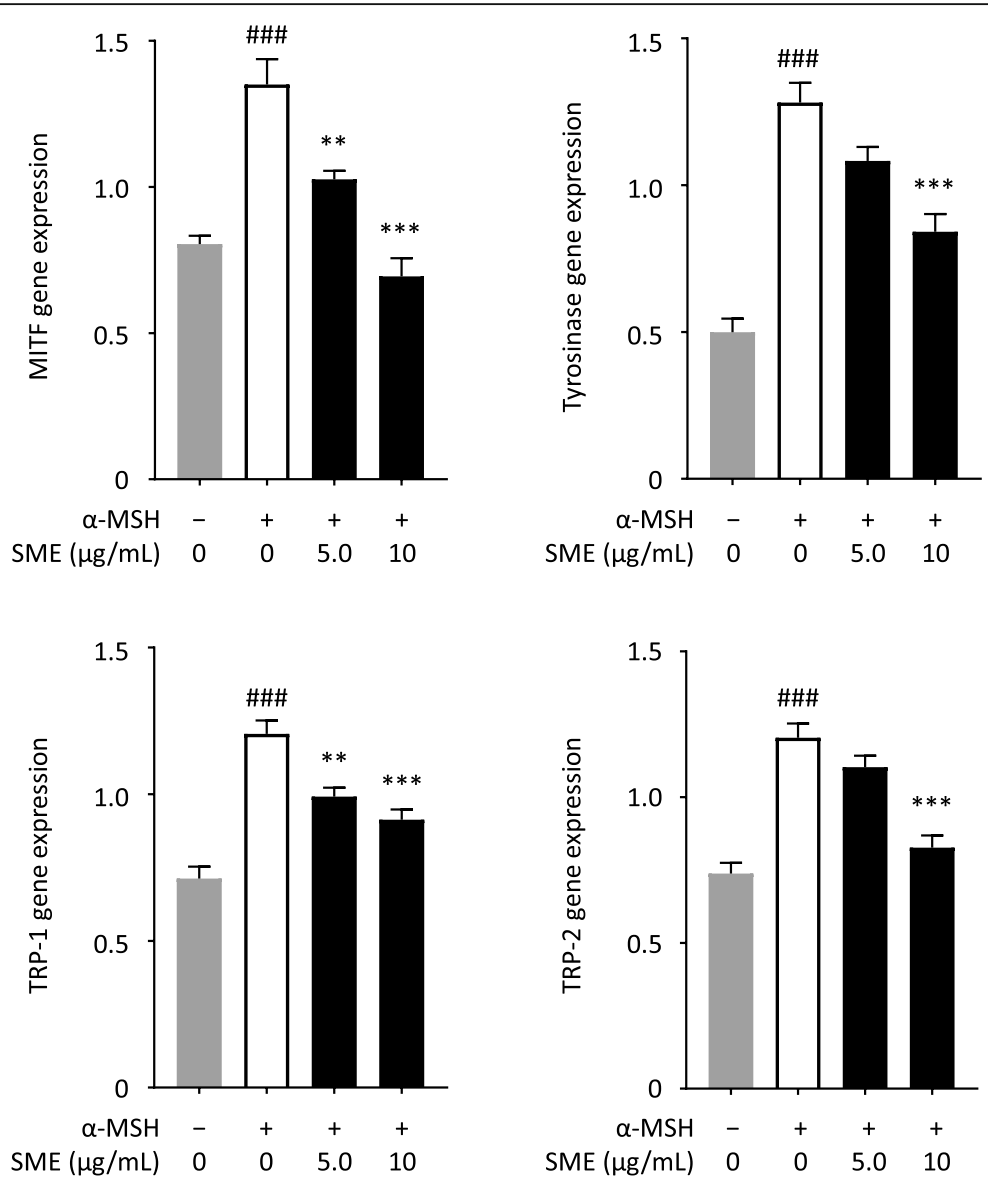

Fig. 4 Effect of SME on mRNA transcription of MITF, tyrosinase, TRP-1, and TRP-2 genes. a-MSH-stimulated cells were treated with SME (5.0 or $10 \mathrm{\mu g} / \mathrm{mL}$ ) for $24 \mathrm{~h}$ and total RNAs were subsequently extracted. Positive control cells were treated with $100 \mathrm{nM}$ a-MSH and $0.1 \%$ DMSO alone, whereas negative control cells with $0.1 \%$ DMSO alone. The RNAs were subjected to qRT-PCR. The mRNA expression levels of MITF, tyrosinase, TRP-1, and TRP-2 were evaluated relative to the level of $\beta$-actin. Values represent the mean \pm SEM from three independent experiments. ${ }^{\# \# \#} p<$ 0.001 versus negative control, ${ }^{* * *} p<0.01,{ }^{* * *} p<0.001$ versus positive control by Tukey's multiple comparison test

market are tyrosinase inhibitors. The effect of SME on the enzymatic activity of tyrosinase was thus evaluated. We found that SME inhibits enzymatic activity of tyrosinase in a dose-dependent manner (Fig. 3); however, the inhibition potency of $10 \mu \mathrm{g} / \mathrm{mL}$ of SME on the tyrosinase activity was lower than that of arbutin. Since melanin production in B16 melanoma 4A5 cells was more strongly inhibited with $10 \mu \mathrm{g} / \mathrm{mL}$ of SME than with arbutin (Fig. 2a), it was assumed that the anti-melanogenic effect of SME was mediated in part by the direct inhibition of tyrosinase activity and by an additional manner different from inhibiting tyrosinase activity.

Tyrosinase, TRP-1, and TRP-2 are the major enzymes involved in melanogenesis. Expression of these three proteins is under the control of MITF, a major regulator for melanogenesis. Gene expression of MITF is induced in response to $\alpha-\mathrm{MSH}$ stimulation. We found that the expression of melanogenic genes, including tyrosinase,
TRP-1, TRP-2, and transcription factor MITF, is significantly downregulated by treating cells with SME (Fig. 4). Zaitsev et al. (1969) have reported that hyperoside (quercetin 3-galactoside) is contained in leaves of S. sorbifolia. Hyperoside has been reported to inhibit tyrosinase activity and expression of TRP-1 and TRP-2 genes (Jung et al. 2014). Thus, the anti-melanogenesis activity of SME might be partially attributed to hyperoside. Further investigations are required to identify the bioactive constituents in SME. Taken together, SME attenuated melanin production through downregulated expression of melanogenesis-related genes.

\section{Conclusions}

In this study, we screened methanolic extracts from leaves of 47 plant species, most of which are native to East Asia, for the inhibitory activity against melanogenesis using B16 melanoma 4A5 cells and found the anti-melanogenesis 


\section{Melanocyte}

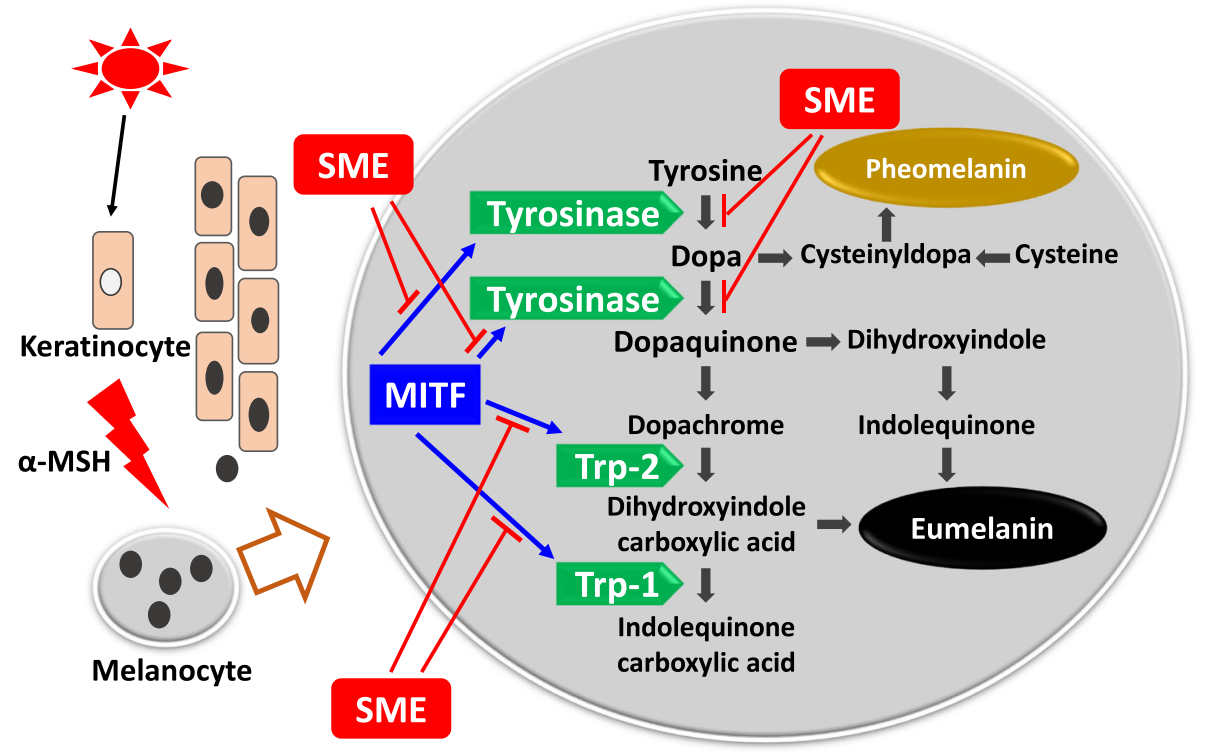

Fig. 5 A scheme showing the mechanism of action of SME in inhibiting melanogenesis

activity in SME. SME exerted the activity through the direct inhibition of enzymatic activity of tyrosinase and downregulated expression of melanogenesis-related genes, such as tyrosinase, MITF, TRP-1, and TRP-2, as summarized in Fig. 5. Overall results showed that SME has a potential to be used as a skin whitening cosmetics agent.

\section{Abbreviations}

Arbutin: 4-Hydroxyphenyl ß-D-glucopyranoside; DHICA: 5,6-Dihydroxyindole2-carboxylic acid; DMEM: Dulbecco's modified Eagle medium; DMSO: Dimethyl sulfoxide; FBS: Fetal bovine serum; L-Dopa: 3-Hydroxy-Ltyrosine; MC1R: Melanocortin 1 receptor; MITF: Microphthalmia-associated transcription factor; NaPB: Sodium phosphate buffer; PBS: Phosphatebuffered saline; GRT-PCR: Quantitative reverse transcription-polymerase chain reaction; SME: Methanolic extract from leaves of S. sorbifolia var. stellipila Max; TRP: Tyrosinase-related protein; WST-8: 2-(2-Methoxy-4-nitrophenyl)-3-(4nitrophenyl)-5-(2,4-disulfophenyl)-2H-tetrazolium, monosodium salt; aMSH: a-Melanocyte-stimulating hormone

\section{Acknowledgements}

Not applicable.

\section{Authors' contributions}

KN conceived the research; MM performed the experiments; DN and JS assisted with the experiments; IHK, MK, and SK contributed to the sample acquisition; KN, MM, and TS analyzed the data; TS provided the experimental equipment; KN wrote the manuscript. All authors read and approved the final manuscript.

\section{Funding}

There was no funding for this research article.

\section{Availability of data and materials}

Material is available on request.

Ethics approval and consent to participate Not applicable.
Consent for publication

Not applicable.

\section{Competing interests}

The authors declare that they have no competing interests.

\section{Author details}

'Department of Bioscience, Graduate School of Agriculture, Ehime University, 3-5-7 Tarumi, Matsuyama, Ehime 790-8566, Japan. ${ }^{2}$ Department of Biological Resources, Faculty of Agriculture, Ehime University, Matsuyama, Ehime, Japan. ${ }^{3}$ Food and Health Sciences Research Center, Ehime University, Matsuyama, Ehime, Japan. ${ }^{4}$ School of Natural Resources and Environmental Sciences, Kangwon National University, Chuncheon, Gangwon-do, Republic of Korea.

Received: 29 November 2019 Accepted: 26 January 2020

Published online: 15 April 2020

\section{References}

Barber JI, Townsend D, Olds DP, King RA. Dopachrome oxidoreductase: a new enzyme in the pigment pathway. J Invest Dermatol. 1984;83:145-9. https:// doi.org/10.1111/1523-1747.ep12263381

Barnetson RS, Ooi TKT, Zhuang L, Halliday GM, Reid CM, Walker PC, Humphrey SM, Kleinig MJ. [Nle ${ }^{4}$-D-Phe $]$-a-melanocyte-stimulating hormone significantly increased pigmentation and decreased UV damage in fair-skinned Caucasian volunteers. J Invest Dermatol. 2006;126:1869-78. https://doi.org/10.1038/sj.jid. 5700317

Bin BH, Kim ST, Bhin J, Lee TR, Cho EG. The development of sugar-based antimelanogenic agents. Int J Mol Sci. 2016;17:583. https://doi.org/10.3390/ ijms17040583

Bolognia J, Murray M, Pawelek J. UVB-induced melanogenesis may be mediated through the MSH-receptor system. J Invest Dermatol. 1989;92:651-6. https:// doi.org/10.1016/0022-202X(89)90177-2

Bourhim T, Villareal MO, Gadhi C, Hafidi A, Isoda H. Depigmenting effect of argan press-cake extract through the down-regulation of Mitf and melanogenic enzymes expression in B16 murine melanoma cells. Cytotechnology. 2018;70: 1389-97. https://doi.org/10.1007/s10616-018-0232-6

Burchill SA, Thody AJ, Ito S. Melanocyte-stimulating hormone, tyrosinase activity and the regulation of eumelanogenesis and phaeomelanogenesis in the hair follicular melanocytes of the mouse. J Endocrinol. 1986;109:15-21. https://doi. org/10.1677/joe.0.1090015 
Buscà R, Ballotti R. Cyclic AMP a key messenger in the regulation of skin pigmentation. Pigment Cell Res. 2000;13:60-9. https://doi.org/10.1034/j.16000749.2000.130203.x

Chakraborty A, Slominski A, Ermak G, Hwang J, Pawelek J. Ultraviolet B and melanocyte-stimulating hormone (MSH) stimulate mRNA production for aMSH receptors and proopiomelanocortin-derived peptides in mouse melanoma cells and transformed keratinocytes. J Invest Dermatol. 1995;105: 655-9. https://doi.org/10.1111/1523-1747.ep12324134

Corre S, Primot A, Sviderskaya E, Bennett DC, Vaulont S, Goding CR, Galibert MD. UVinduced expression of key component of the tanning process, the POMC and MC1R genes, is dependent on the $\mathrm{p}$-38-activated upstream stimulating factor-1 (USF-1). J Biol Chem. 2004;279:51226-33. https://doi.org/10.1074/jbc.M409768200

Costin GE, Hearing VJ. Human skin pigmentation: melanocytes modulate skin color in response to stress. FASEB J. 2007;21:976-94. https://doi.org/10.1096/ fj.06-6649rev

D'Mello SAN, Finlay GJ, Baguley BC, Askarian-Amiri ME. Signaling pathways in melanogenesis. Int J Mol Sci. 2016;17:1144. https://doi.org/10.3390/ ijms17071144

Gunia-Krzyżak A, Popiol J, Marona H. Melanogenesis inhibitors: strategies for searching for and evaluation of active compounds. Curr Med Chem. 2016;23: 3548-74. https://doi.org/10.2174/0929867323666160627094938

Hearing VJ, Tsukamoto K. Enzymatic control of pigmentation in mammals. FASEB J. 1991;5:2902-9. https://doi.org/10.1096/fasebj.5.14.1752358

Hu ZM, Zhou Q, Lei TC, Ding SF, Xu SZ. Effects of hydroquinone and its glucoside derivatives on melanogenesis and antioxidation: biosafety as skin whitening agents. J Dermatol Sci. 2009;55:179-84. https://doi.org/10.1016/j. jdermsci.2009.06.003

Ito S, Wakamatsu K. Quantitative analysis of eumelanin and pheomelanin in humans, mice, and other animals: a comparative review. Pigment Cell Res. 2003;16:523-31. https://doi.org/10.1034/j.1600-0749.2003.00072.x

Jung SY, Jung WS, Jung HK, Lee GH, Cho JH, Cho HW, Choi IY. The mixture of different parts of Nelumbo nucifera and two bioactive components inhibited tyrosinase activity and melanogenesis. J Cosmet Sci. 2014;65:377-88.

Kim DK, Choi SH, Lee JO, Ryu SY, Park DK, Shin DH, Jung JH, Pyo SK, Lee KR, Zee OP. Cytotoxic constituents of Sorbaria sorbifolia var. stellipila. Arch Pharm Res. 1997;20:85-7. https://doi.org/10.1007/BF02974048

Kobayashi T, Urabe K, Winder A, Jiménez-Cervantes C, Imokawa G, Brewington T, Solano F, García-Borrón JC, Hearing VJ. Tyrosinase related protein 1 (TRP1) functions as a DHICA oxidase in melanin biosynthesis. EMBO J. 1994;13:581825. https://doi.org/10.1002/j.1460-2075.1994.tb06925.x

Lee SY, Baek N, Nam TG. Natural, semisynthetic and synthetic tyrosinase inhibitors. J Enzym Inhib Med Chem. 2016;31:1-13. https://doi.org/10.3109/ 14756366.2015.1004058

Lee WJ, Rhee DY, Bang SH, Kim SY, Won CH, Lee MW, Choi JH, Chang SE. The natural yeast extract isolated by ethanol precipitation inhibits melanin synthesis by modulating tyrosinase activity and downregulating melanosome transfer. Biosci Biotechnol Biochem. 2015;79:1504-11. https:// doi.org/10.1080/09168451.2015.1032880

Nishi K, Kondo A, Okamoto T, Nakano H, Daifuku M, Nishimoto S, Ochi K, Takaoka $\mathrm{T}$, Sugahara T. Immunostimulatory in vitro and in vivo effects of a watersoluble extract from kale. Biosci Biotechnol Biochem. 2011;75:40-6. https:// doi.org/10.1271/bbb.100490

Rodríguez Cl, Setaluri V. Cyclic AMP (CAMP) signaling in melanocytes and melanoma. Arch Biochem Biophys. 2014;563:22-7. https://doi.org/10.1016/j. abb.2014.07.003

Sakuma K, Ogawa M, Sugibayashi K, Yamada K, Yamamoto K. Relationship between tyrosinase inhibitory action and oxidation-reduction potential of cosmetic whitening ingredients and phenol derivatives. Arch Pharm Res. 1999;22:335-9. https://doi.org/10.1007/BF02979054

Seo GY, Ha Y, Park AH, Kwon OW, Kim YJ. Leathesia difformis extract inhibits aMSH-induced melanogenesis in B16F10 cells via down-regulation of CREB signaling pathway. Int J Mol Sci. 2019;20:536. https://doi.org/10.3390/ ijms20030536

Skoczyńska A, Budzisz E, Trznadel-Grodzka E, Rotsztejn H. Melanin and lipofuscin as hallmarks of skin aging. Adv Dermatol Allergol. 2017;34:97-103. https://doi. org/10.5114/ada.2017.67070

Smit N, Vicanova J, Pavel S. The hunt for natural skin whitening agents. Int J Mol Sci. 2009;10:5326-49. https://doi.org/10.3390/ijms10125326

Solano F. Melanins: skin pigments and much more-types, structural models, biological functions, and formation routes. New J Sci. 2014;2014:498276. https://doi.org/10.1155/2014/498276
Vachtenheim J, Borovanský J. "Transcription physiology" of pigment formation in melanocytes: central role of MITF. Exp Dermatol. 2010;19:617-27. https://doi. org/10.1111/j.1600-0625.2009.01053.x

Wang YC, Haung XY, Chiu CC, Lin MY, Lin WH, Chang WT, Tseng CC, Wang HMD. Inhibitions of melanogenesis via Phyllanthus emblica fruit extract powder in B16F10 cells. Food Biosci. 2019;28:177-82. https://doi.org/10.1016/j.fbio.2019.01.006

Yang YK, Dickinson C, Haskell-Luevano C, Gantz I. Molecular basis for the interaction of $\left[\mathrm{Nle}^{4}, \mathrm{D}-\mathrm{Phe}^{7}\right]$ melanocyte stimulating hormone with the human melanocortin-1 receptor (melanocyte a-MSH receptor). J Biol Chem. 1997;272:23000-10. https://doi.org/10.1074/jbc.272.37.23000

Zaitsev VG, Makarova GV, Komissarenko NF. Sorbifolin-a new flavone glycoside from Sorbaria sorbifolia. ChemNat Compd. 1969;5:423-6. https://doi.org/10. 1007/BF00568581

\section{Publisher's Note}

Springer Nature remains neutral with regard to jurisdictional claims in published maps and institutional affiliations.
Ready to submit your research? Choose BMC and benefit from:

- fast, convenient online submission

- thorough peer review by experienced researchers in your field

- rapid publication on acceptance

- support for research data, including large and complex data types

- gold Open Access which fosters wider collaboration and increased citations

- maximum visibility for your research: over $100 \mathrm{M}$ website views per year

At BMC, research is always in progress.

Learn more biomedcentral.com/submissions 